IZA DP No. 4587

Adverse Workplace Conditions, High-Involvement Work Practices and Labor Turnover: Evidence from Danish Linked Employer-Employee Data

Elena Cottini

Takao Kato

Niels Westergaard Nielsen

November 2009 


\title{
Adverse Workplace Conditions, High-Involvement Work Practices and Labor Turnover: Evidence from Danish Linked Employer-Employee Data
}

\author{
Elena Cottini \\ Università Cattolica del Sacro Cuore \\ and CCP, Aarhus School of Business \\ Takao Kato \\ Colgate University, CJEB (Columbia), \\ TCER (Tokyo), CCP (Aarhus) and IZA
}

Niels Westergaard Nielsen

$C C P$, Aarhus School of Business

and IZA

Discussion Paper No. 4587

November 2009

\author{
IZA \\ P.O. Box 7240 \\ 53072 Bonn \\ Germany
}

Phone: +49-228-3894-0

Fax: +49-228-3894-180

E-mail: iza@iza.org

\begin{abstract}
Any opinions expressed here are those of the author(s) and not those of IZA. Research published in this series may include views on policy, but the institute itself takes no institutional policy positions.

The Institute for the Study of Labor (IZA) in Bonn is a local and virtual international research center and a place of communication between science, politics and business. IZA is an independent nonprofit organization supported by Deutsche Post Foundation. The center is associated with the University of Bonn and offers a stimulating research environment through its international network, workshops and conferences, data service, project support, research visits and doctoral program. IZA engages in (i) original and internationally competitive research in all fields of labor economics, (ii) development of policy concepts, and (iii) dissemination of research results and concepts to the interested public.
\end{abstract}

IZA Discussion Papers often represent preliminary work and are circulated to encourage discussion. Citation of such a paper should account for its provisional character. A revised version may be available directly from the author. 


\section{ABSTRACT}

\section{Adverse Workplace Conditions, High-Involvement Work Practices and Labor Turnover: Evidence from Danish Linked Employer-Employee Data*}

This paper contributes to the emerging strand of the empirical literature that takes advantage of new data on workplace-specific job attributes and voluntary employee turnover to shed fresh insights on the relationship between employee turnover, adverse workplace conditions and HRM environments. We find evidence that workers in hazardous workplace conditions are indeed more likely to separate from their current employers voluntarily while HighInvolvement Work Practices (HIWPs) reduces employee turnover. Specifically, exposing a worker to physical hazards such as loud noise, vibration or poor lighting will lead to a 3 percentage point increase in the probability of turnover from the average turnover rate of 18 percent; working in a fixed night shift will result in an 11 percentage point jump in the turnover probability, and having an unsupportive boss will lead to a 5 percentage point increase. The effect of HIWPs is modest yet hardly negligible with a 4 percentage point reduction in the turnover probability from having voice in the workplace. Furthermore the turnover-increasing effect of physical hazards is found to be significantly reduced by the presence of strong information sharing whereas the adverse effect on turnover of the use of fixed night shift is also found to be significantly mitigated by the authority delegation to workers by management. As such, our evidence lends support to those who advocate the use of HIWPs for those firms with employee turnover problems due to hazardous workplace conditions. Finally, our logit analysis of the 5-year odds of improving workplace conditions suggests that the worker exposed to adverse workplace conditions can improve her long-term odds of rectifying such workplace adversities significantly by separating from the firm voluntarily. Voluntary turnover appears to be a rational worker response to adverse workplace conditions, and unless the firm alleviates its adverse workplace conditions directly or mitigates their effects on voluntary turnover through HIWPs, workers exposed to adverse workplace conditions will likely continue to take the exit option.

JEL Classification: M5, J63, J81, J28, J5

Keywords: employee turnover, workplace conditions, human resource management, high-involvement work system, high-performance work system

Corresponding author:

Takao Kato

Department of Economics

Colgate University

13 Oak Drive

Hamilton, NY 13346

USA

E-mail: tkato@colgate.edu

\footnotetext{
* National Research Centre for the Working Environment is the provider of the work environment data used in this project. We also thank Kenneth Lykke Sørensen and Philip Røpcke for help with handling the data. This research is part of a larger project funded by the Danish Work Environment Authority (DWEA). The usual disclaimers apply.
} 


\section{Adverse Workplace Conditions, High-Involvement Work Practices and Labor Turnover: Evidence from Danish Linked Employer-Employee Data}

\section{Introduction}

In the textbook competitive labour market in which wages compensate perfectly for various working conditions, there is no particular incentive for workers to separate from their current jobs. Moreover, there is no reason to expect systematic linkage between adverse working conditions and employee turnover. Notwithstanding such textbook conjectures, there is a great deal of micro-level evidence on the dynamics of labour market (Davis and Haltiwanger 1999, Farber 1999). Extensive analysis of turnover has been carried out in the fields of human resource management (HRM) and personnel psychology, where attention centers on the personnel policies and job attitudes of the employees. There is also, however, an increasing interest in labor economics to incorporate information on workplace conditions and worker attitudes into the analysis of labor turnover.

Previously, empirical studies have analyzed directly how individual characteristics and working conditions or job attributes affect employees' probability of quitting or their job duration. Adverse workplace conditions have been found to increase quits. In most of these studies the data on workplace conditions are not from individual employees' workplaces, but rely on, for example, industry injury rates or work attributes typical of different occupations (e.g. Viscusi 1979; Bartel 1982; Herzog and Schottman 1990; Gronberg and Reed 1994). Another strand of the literature explains quits or job durations directly by means of job satisfaction scores, the employee's characteristics, and firm characteristics, but without information on job attributes (e.g. Flanagan et al. 1974; Freeman 1978; Clark et al. 1998; Ward and Sloane 2000; Clark 2001; Kristensen and Westergaård-Nielsen 2004; Delfgaauw 2007; Lévy-Garboua et al. 2007). These 
studies discover that dissatisfied workers are more likely to separate from their current matches. In other words, the self-assessed level of job satisfaction is a good predictor for job mobility beyond wages. Working the other way, Akerlof, Rose and Yellen (1988) show that job changes lead to an increase in job satisfaction and Altonji and Paxson (1988) present evidence that job mobility leads to more satisfactory working hours.

More recent studies started to take advantage of the emerging availability of detailed data on workplace-specific attributes as opposed to industry-specific or occupation-specific attributes. Thus, Garcia Serrano (2004) uses the Spanish Working Conditions Survey (SWCS) for 2001, which is a nationally representative random sample survey of all employed (having worked at least 1 hour in the week preceding the interview week) individuals aged 16 years and above. It contains worker individual characteristics and also firm characteristics or characteristics related to the job of the worker such as sector, industry, firm size, type of contract (temporary, permanent), occupation, and firm tenure, provided by the worker at the time of the survey interview. The dataset collects specific self-assessed workplace features such as psychosocial and physical environmental characteristics, similar to the ones in the data we have (see the data description section below). Furthermore all sampled workers were asked whether they consider leaving/think they will have to leave their current jobs within a year and if so for which reason (several alternatives are given). This information is used to construct an expected exit hazard that is the dependent variable in their study. Their main focus is to highlight the differences between the temporary vs. permanent employees.

Bockermann and Llmakunnas (2009) use individual specific working conditions data from Finland and analyses quit intentions and actual separations and provide novel findings 
concerning interplay between adverse workplace conditions, job satisfaction, and employees' intentions to quit and actual separations.

This paper is aimed at contributing to the emerging strand of the empirical literature that takes advantage of new data on workplace-specific job attributes and voluntary employee turnover to shed fresh insights on the relationship between employee turnover and adverse workplace conditions and HRM environments. Our paper represents one of the first serious attempts to marry the two separately-developed literatures, the High-Involvement Work System (or High Performance Work System) literature and the employee turnover literature with particular focus on adverse workplace conditions. We do so by studying not only a variety of adverse workplace conditions but also several key elements of the High-Involvement Work System as possible determinants of employee turnover, and exploring potentially important interplay between the two. The High-Involvement Work System consists of several key human resource policies and workplace practices (High-Involvement Work Practices, HIWPs) which aim at taping into the ability of frontline workers to produce valuable local knowledge through their efforts and share it with management; and engage in local problem solving autonomously. A limited number of prior studies on the High-Involvement Work System suggest that such a system may reduce employee turnover.

We find evidence that workers in hazardous workplace conditions are indeed more likely to separate from their current employers voluntarily while the High-Involvement Work System reduces employee turnover. Specifically, exposing a worker to physical hazards such as loud noise, vibration or poor lighting will lead to a 3 percentage point increase in the probability of turnover from the average turnover rate of 18 percent; working in a fixed night shift will result in an 11 percentage point jump in the turnover probability, and having an unsupportive boss will 
lead to a 5 percentage point increase. The effects of HIWPs are modest yet hardly negligible with a 4 percentage point reduction in the turnover probability from having voice in the workplace.

In addition, we find some evidence for the role that HIWPs play in mitigating the effects on turnover of adverse workplace conditions. Or the turnover-increasing effect of physical hazards is found to be significantly reduced by the presence of strong information sharing whereas the turnover-fostering effect of the use of fixed night shift is also found to be significantly mitigated by the authority delegation to workers by management. As such, our evidence lends support to those who advocate the use of High-Involvement Work System for those firms with employee turnover problems due to hazardous workplace conditions.

Finally, we link the 2000 data to the 2005 data (only made available a few months ago) and present new evidence on the long-run consequence of voluntary turnover on workplace conditions and HRM environments. Our logit analysis of the odds of improving workplace conditions and HRM environments suggests that the worker exposed to adverse workplace conditions and HRM environments can improve her odds of rectifying such workplace adversities in five years significantly by separating from the firm voluntarily. In short, voluntary turnover appears to be a rational worker response to adverse workplace conditions. Unless the firm actually alleviates its adverse workplace conditions directly or mitigates their effects on voluntary turnover through HIWPs, workers exposed to adverse workplace conditions will continue to take the exit option.

The paper is organized as follows. The next section discusses the empirical strategy, followed by Section 3 in which we present the econometric specifications and our main findings. Section 4 provides additional evidence on the long-run consequences on workplace conditions and HRM environments of voluntary turnover, followed by the concluding section. 


\section{Empirical Strategy}

\subsection{Data}

The data we use in this paper derive from two sources. The first is Statistics Denmark Integrated Labour Market Database (IDA) from Statistics Denmark. ${ }^{1}$ IDA provides detailed information on the population of all Danish establishments and all individuals between 15 and 74 years old who legally reside in Denmark every year (the data are collected in November of each year). Importantly data on establishments are consistently linked to data on individuals, using the unique identification numbers assigned to all establishments and individuals.

Second, we match IDA with "The Danish Work Environment Cohort Study (DWECS)" collected by the National Research Center for the Working Environment that provides unusually rich information on working conditions and exposures to occupational hazards at the individual level. The DWECS consists of a split panel collected every 5 years from 1990 to $2005^{2}$ on individuals that were employed at the time of interview (October-December of the survey year) or had been employees within two months prior to the date of the interview. The questionnaire contains detailed work environment hazard information, such as exposure to physical agents (noise, radiation, vibration, etc.), thermal fluctuations, chemical and biological agents, scheduling hazards (shift, night work, etc.), social environment indicators (participation and consultation with boss or co-workers and conflicts at work). For the last two waves (2000 and

\footnotetext{
${ }^{1}$ Due to its completeness and richness of the data, the use of IDA in labor market studies has been rapidly rising (see, for instance, Bingley and Westergård-Nielsen (2003), Buhai et. al (2008), Grund and Westergård-Nielsen (2009).

${ }_{2}$ The 1990 panel consists of a random sample of people aged 18-59 years on 1st October 1990 drawn from the central population register that were interviewed again in 1995, 2000 and 2005 irrespective of participation in previous rounds
} 
2005) the survey contains a set of information on human resource management practices as well. The focus of this paper is to study the relationship between a variety of workplace hazards and labor turnover, and how such relationships can be tempered by human resource management practices. Though the DWECS contains workers in the public sector, we exclude those public sector workers from our analysis in this paper since we presently do not have sufficient information to define voluntary turnover with precision for such public sector workers.

There are several advantages of the use of the Danish data. First, most prior studies use subjective measures of employee turnover, such as whether the individual intends to separate from the firm. It is possible that individuals with generally negative and pessimistic dispositions express somewhat negative views on all subjective measures including subjective measures of their turnover intentions and their perceptions on working conditions and hazards. As such, the lack of an objective measure of employee turnover makes it particularly difficult to draw any causal implications from observed positive correlations between subjective measures of employee turnover and perceived working conditions and hazards. Our data allow for the use of an objective measure of employee turnover and hence alleviate this potentially important shortcoming. Furthermore, the data include information on the causes of labor turnover which can be used to separate voluntary turnover (quit) from involuntary turnover (layoff). Specifically we define voluntary turnover as opposed to involuntary turnover, based on what each worker considers the primary reason for her separation. As such, we will be able to focus on the relationship between adverse working conditions and voluntary turnover (as opposed to general turnover including both voluntary and involuntary turnover). ${ }^{3}$

\footnotetext{
${ }^{3}$ A number of studies report evidence on the importance of distinguishing quits from layoffs (see, for instance, Kidd, 1994).
} 
Second, data on working conditions and workplace hazards are more precise and detailed than most other data used by prior studies (see, for example, Garcia-Serrano, 2004).

Third, our Danish data provide for the first time detailed information not only on adverse working conditions and hazards but also on human resource management practices (while the Finnish data used by Bockermann and Illmakunnas, 2009 are rich in information on adverse working conditions and hazards, they have only limited information on human resource management practices).

Fourth, as discussed before, linking the 2000 survey to IDA, we are able to examine whether individuals with adverse working conditions in 2000 were more likely to separate from their firms in 2001. Since the same individuals responded to the same set of questions on workplace hazards and HRM in 2005 again, we are further able to find out whether those individuals with adverse working conditions who separated from their firms are actually working in improved working conditions in 2005. On our reading of the literature no prior work was able to have such detailed longitudinal data on adverse working conditions and HRM as well as on employee turnover.

Finally, Denmark is an excellent case study on this subject not only for the remarkably rich, complete and reliable data but also for the potentially important role that non-pecuniary factors play in job mobility, given the relatively high job mobility in spite of considerably wage compression (Eriksson and Westergaard-Nielsen, 2007).

\subsection{Adverse Workplace Conditions and Voluntary Labor Turnover}

Our data provide unusually detailed information on a variety of adverse working conditions that may influence individual worker's separation decision. To facilitate comparison with other 
studies we use several aspects of working conditions that has been shown to be significant in describing working conditions at the firm. ${ }^{4}$ First, the data enable us to create the following three key work environmental hazard variables:

1. PHYHAZARD takes a value of one if at the time of the interview the worker was exposed to: (i) noise so loud that he/she has to raise his/her voice to talk with other people; (ii) vibrations from hand tools; (iii) vibrations from strike his/her whole body; or (iv) bad lighting, zero otherwise.

2. THERMHAZARD takes a value of one if at the time of the interview the worker was exposed to: (i) heat so he/she sweats/perspires even if he/she does not move; (ii) heat that makes his/her drowsy and sleepy; (iii) temperature fluctuations; (iv) coldness (work outdoor or in cold rooms); (v) draft; or (vi) dry air at the workplace, zero otherwise.

3. CHEMHAZARD takes a value of one if at the time of the interview the worker was exposed to: (i) skin contact with refrigerants (coolants) or lubricants; (ii) skin contact with cleaning materials/disinfectants; (iii) solvent vapor; (iv) oil mist/oil vapor /haze; or (v) passive smoke.

As shown in Table 1, over 40 percent of workers were exposed to physical hazards and thermal hazards at work in 2000 (mean value of PHYHAZARD=0.44 and THERMHAZARD=0.43). Exposure to chemical hazards at work appeared to be less common yet still one in five workers were exposed to such hazards at work in 2000 (mean value of CHEMHAZARD=0.29). The table also shows that the proportion of workers who were exposed to physical and thermal hazards was higher among separating workers with TURNOVER=1 than among remaining workers with TURNOVER=0, suggesting that exposure to such hazards might have been a cause for voluntary labor turnover. Note that TURNOVER=1 if during 2000

\footnotetext{
${ }^{4}$ See, for example, Karasek and Theorell (1990) and Siegrist (1996).
} 
(November 2000-October 2001) the worker separates voluntarily from the firm she was originally registered for as an employee at the beginning of the year (November 2000), zero otherwise and that all data on her workplace conditions are about the firm she was originally registered for as an employee at the beginning of the year (November 2000). As such, TURNOVER and all workplace condition variables such as PHYHAZARD are appropriately constructed to test the above conjecture that exposure to workplace hazards increases the worker's probability to quit.

Second, we are able to consider the possible impact on the worker's separation decision of potentially undesirable work schedules. Specifically, we consider SHIFTWORK=1 if the worker worked in shifts ( 2 or 3 shifts) in 2000, 0 otherwise; NIGHTSHIFT=1 if the worker works in fixed night shifts, zero otherwise; EVENINGSHIFT=1 if the worker works in fixed evening shifts, zero otherwise; and MORNINGSHIFT=1 if the worker works in fixed morning shifts, zero otherwise. Table 1 shows that over one in ten workers work in shifts and that about 2 percent of workers work in fixed evening shifts with another 2 percent of workers in fixed night shifts, and only 0.4 percent in fixed morning shifts. The proportion of workers in fixed night shifts is higher among separating workers than among remaining workers (2.9 vs. 1.4 percent). It implies that some workers may consider working in fixed night shifts a significant scheduling hazard and contemplate on quitting their current jobs.

Third, the lack of support in the workplace can be an important catalyst for voluntary labor turnover. We are fortunate that the data allow for the construction of unusual variables which capture two crucial aspects of supportive workplace (or lack thereof): (i) NOBOSSHELP $=1$ if the worker never or rarely receives help from his/her boss, zero otherwise; and (ii) NOPEERHELP=1 if the worker never or rarely receives help from his/her colleagues, 
zero otherwise. As shown in Table 1, close to one in five workers report that they never or rarely receive help from their bosses. The lack of peer support at work seems to be less prevalent (less than one in ten workers report such lack of peer support at work). Again, unsupportive boss is considerably more common among separating workers than among remaining workers (24 vs. 17 percent).

Fourth, a set of variables are created to gauge the extent of workplace conflict: BULLYING=1 if the worker is at least to some degree exposed to bulling at work, zero otherwise; UNWANTEDSEX=1 if the worker is at least to some degree exposed to unwanted sexual attention at work, zero otherwise; and VIOLENCE $=1$ if the worker is at least to some degree exposed to violence at work, zero otherwise. As shown in Table 1, about 5 percent of workers report some exposure to bulling and violence at work whereas 1.3 percent report unwanted sexual attention at work. The difference in the incidence of such workplace conflict between separating and remaining workers does not appear to point to any systematic pattern.

Finally, we also consider the repetitive nature of work as a possible cause of voluntary labor turnover, REPETITIVE=1 if the worker responds that his/her work requires that he/she repeats the same task many times in an hour, zero otherwise. A little over 50 percent of workers report that they work in such repetitive jobs, and repetitive work seems to be somewhat more wide-spread among separating workers.

\subsection{High-Involvement Work Practices and Labor Turnover}

One of the most important changes in the workplace in many industrialized countries in the last two decades or so is the emergence of innovative new work practices often referred to as High-Performance Work Practices (HPWPs) or High-Involvement Work Practices (HIWPs). 
In stark contrast to the traditional employment system, HIWPs are based on a premise that frontline workers can play a significant role in enhancing the firm's overall competitiveness in the market. ${ }^{5}$ First, frontline workers acquire a variety of local knowledge through their frequent interactions with their equipments in the case of manufacturing and their customers in the case of service. Some of such local knowledge may prove to be a significant source of competitive edge for the firm (e.g., implementing a series of small yet useful ideas to improve productivity, quality, and customer satisfaction and reduce costs may eventually help the firm out-compete its rivals).

Second, the firm encounters a variety of shocks. Some of such shocks are local in nature and dealt with most effectively by frontline workers themselves without involving formal and inevitably time-consuming interventions from higher-level management. ${ }^{6}$

In short, HIWPs consist of a variety of human resource policies and workplace practices which aim at taping into the ability of frontline workers to produce valuable local knowledge through their efforts and share it with management; and deal with local shocks autonomously. There is an enormous amount of previous empirical work by economists in this broad area and especially as it concerns the impact of such new work practices upon business performance. ${ }^{7}$ However, for the most part the empirical economics literature has not paid detailed attention to

\footnotetext{
${ }^{5}$ We define frontline workers broadly, including all workers who are working in trenches, regularly interacting with machines in the case of manufacturing and customers in the case of service (such as machine operators, customer service representatives, sales professionals, and lower-level engineers and managers).

${ }^{6}$ See, for instance, Koike (2005).

${ }^{7}$ See, for example, Huselid and Becker (1996), Dunlop and Weil (1996), Berg (1996), Ichniowski, Shaw and Prennushi (1997), Freeman, Kleiner, and Ostroff (2000), Cappelli and Neumark (2001), Boning, Ichniowski , and Shaw (2007), Black and Lynch (2001, 2004), and Bartel (2004) for the U.S.; Jones and Kato (1995) and Kato and Morishima (2002) for Japan; Leoni, et. al. (2001) for Italy; Addison and Belfield (2000); Conyon and Freeman (2001); and DeVaro (2006), and Heywood, Jirjahn, and Wei (2008) for the U.K.; Eriksson (2003) for Denmark; Jones, Kalmi and Kauhanen (2006) for Finland; Bayo-Moriones, et. al. (2003) for Spain; and Zwick (2004) for Germany. In addition to the economics literature, there is a wealth of relevant literature in the field of management (see, for example, Lawler, Mohrman and Ledford, 1995 and Becker and Huselid, 1998).
} 
the actual process/mechanism through which HIWPs result in better enterprise performance. In other words, we know a lot about whether HIWPs improve enterprise performance but we do not know much about how they do it. There are, however, a handful of studies that do make important steps in beginning to uncover such process/mechanism. First, a number of pioneering studies (e.g. Lazear, 2000, Kleiner and Helper, 2003, Fernie and Metcalf, 1999, Paarsh and Shearer, 1999, and Knez and Simester, 2001), focus on the effects on individual worker performance of the switch from time rates to piece rates or to performance pay, and provide direct evidence on the impact of performance pay upon individual worker behavior. A related line of work examines the effects on individual worker performance of the shift to team production (e.g. Batt, 1999 and Hamilton, Nickerson and Owan, 2002). Grant, Ichniowski and Shaw (2002) studies the impact of HIWPs on the nature of social networks and knowledge sharing among workers.

This paper contributes to this small yet growing literature on how HIWPs work. Specifically as we argued above, the High Involvement Work System taps into each worker's initiative, creativity and resourcefulness. To do so, the firm will need to: (i) make workers fully informed of what is happening at their workplaces (information sharing); (ii) empower them when it comes to workplace decision making (voice); and (iii) provide them with adequate training (training). Such workers under the High Involvement Work System are less likely to separate from the firm. First, much of information shared under the High Involvement Work System tends to be rather specific to the firm or even to the workplace. Second, training received by workers under the High Involvement Work System is also often specific to the firm. The standard human capital theory predicts that workers with such firm-specific knowledge and skill are less likely to separate from the firm (Becker, 1964). 
Workers under the High Involvement Work System are also provided with opportunities to influence workplace decisions affecting their work (voice). The exit-voice theory predicts that such workers with voice are less likely to select the exit option (Freeman, 1976).

In short, both the human capital theory and the exit-voice theory predict that workers under the High Involvement Work System are less likely to separate from their firms, and hence HIWPs result in lower labor turnover. Though the literature on the effects on labor turnover of HIWPs is thin, compared to work on the effects on productivity of HIWPs, certainly we are not the first to study this issue. We can trace the literature back at least to Huselid (1995), followed by a number of important studies, such as Batt, Colvin and Keefe (2002), Batt and Valcour (2003), Batt (2004), Bauer and Bender (2004), Doellgast (2008), and Askenazy and Galbis (2008). However, on our reading of the literature, we are the first to examine the effect on employee turnover of HIWPs in conjunction with a rich set of adverse workplace conditions. As such, we study for the first time the potentially important role of HIWPs in alleviating the effects on employee turnover of adverse workplace conditions (see below for more details).

Our data enable us to consider three variables which capture the three key elements of the High Involvement Work System: (i) VOICE=1 if the worker always, often or sometimes has much influence on decisions concerning his/her work, zero otherwise; (ii) INFOSHARE=1 if the worker is always or often informed of the decisions affecting his/her workplace, zero otherwise; and (iii) TRAINING=1 if the worker has participated in courses or on-the-training at his/her present workplace within the last 12 months, zero otherwise. Note that we are mindful of the potentially important measurement issue concerning TRAINING, or the training variable is somewhat too general to capture the intensity of training specific to the High-Involvement Work System. The results regarding TRAINING ought to be interpreted with caution. 
Table 1 shows: that close to 80 percent of workers report that they always, often or sometimes has much influence on decisions concerning his/her work; that an even higher proportion of workers (90 percent) report that they are always or often informed of the decisions affecting their workplaces; and that about one in two workers have participated in courses or onthe-job training in the workplace during the last twelve months. The proportion of workers under the High Involvement Work System with VOICE=1, INFOSHARE=1, and TRAINING=1 is higher among remaining workers than among separating workers, pointing to the possibility of the turnover-reducing effect of HIWPs.

\subsection{HIWPs and the turnover-increasing effect of adverse working conditions}

The turnover-increasing effect of adverse workplace conditions can be tempered by HIWPs. Let us demonstrate this point by providing two specific examples. First, as discussed earlier, exposure to work environmental hazards can be a cause for employee turnover. Employees who are exposed to such hazards may be more nervous about the nature and scope of such hazards when they feel they are not fully informed about their workplaces by the firm. HIWPs with strong information sharing help workers feel as if they are fully informed of the nature and scope of their work environmental hazards. As such HIWPs with strong information sharing can moderate the turnover-increasing effects of work environmental hazards.

Second, in general working in fixed night shifts is not conducive to normal social and family life, and hence considered an adverse workplace condition by many workers. However, night shift work tends to give workers more freedom over how work is done (such as baking jobs in night shifts and security guard in night shifts). By strengthening worker voice, HIWPs can 
reinforce such an advantage of night shift work and hence temper the overall negative effect on employee turnover of night shifts.

\section{Econometric Specifications and Results}

As is often done in the literature, we estimate a logit model of voluntary employee turnover augmented by a comprehensive set of adverse workplace condition and HIWP variables as explained in the previous section. Specifically,

(1) $\ln [\operatorname{Pr}($ TURNOVER $) / 1-\operatorname{Pr}($ TURNOVER $)]=\alpha+\lambda$ ADVERSEWORK $+\mu$ HIWP

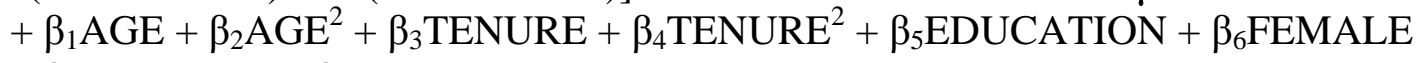
$+\beta_{7}$ MARRIED $+\beta_{8} \ln ($ ORWAGE)

$+\gamma$ OCCUPATION $+\delta$ INDUSTRY $+\phi R E G I O N+\varepsilon$ FIRMSIZE $+u$

where ADVERSEWORK=a vector of adverse workplace condition variables as explained in the previous section; HIWP=a vector of HIWPs as explained in the previous section; AGE=age of the worker; TENURE=tenure (in years) of the worker with the firm which he/she was registered for as an employee at the beginning of the year (November 2000); EDUCATION=years of schooling; FEMALE=1 if the worker is female, zero otherwise; MARRIED=1 if the worker is married, zero otherwise; ORWAGE=objective measure of relative wage (see below for more details); OCCUPATION= a vector of six occupation dummy variables (one of which is omitted as a reference category; INDUSTRY=a vector of 12 industry dummy variables (one of which is omitted as a reference category); $\mathbf{R E G I O N = a ~ v e c t o r ~ o f ~} 12$ region dummy variables (one of which is omitted as a reference category); FIRMSIZE=a vector of four firm size categories (one of which is omitted as a reference category); $\alpha, \beta_{1}, \beta_{2}$, and $\beta_{8}$ are the coefficients to be estimated;

$\lambda, \mu, \gamma, \delta, \phi$, and $\varepsilon$ are vectors of coefficients to be estimated; and $\mathrm{u}$ is the disturbance term.

For ORWAGE, we first estimate a standard Mincerian wage equation and then for each worker, we calculate the difference between his/her actual wage and his/her predicted wage from 
the estimated wage equation. We hypothesize that the worker with a larger gap between his/her actual wage and his/her predicted wage is less likely to separate voluntarily from the firm, all other things being equal. Our data also provide information on a subjective measure of relative wage, PRWAGE=1 if the worker considers his/her current wage relative to his/her effort level and qualifications "high” or “appropriate” as opposed to “, zero otherwise. As shown below, reassuringly the use of this subjective measure instead of ORWAGE changes our key results little.

Table 1 presents summary statistics for the whole sample as well as for the separating workers with TURNOVER=1 and the remaining workers with TURNOVER $=0$ separately. Since we have already discussed summary statistics on adverse workplace conditions and HIWPs in the previous section, here we provide a brief discussion on TURNOVER and control variables. The Table shows that the annual average rate of voluntary employee turnover (the probability of the average worker to separate voluntarily from her present firm by the end of the year) is approximately 18 percent. The average worker is 39 years old with 5.7 years of tenure, and 12.9 years of schooling. Forty five percent of workers are female and 52 percent are married. A comparison between the last two columns with TURNOVER=1 and TURNOVER=0 show that the separating workers are younger with shorter tenure and are less likely to be female, and married than the remaining workers.

Column (i) of Table 2 shows the maximum likelihood estimates of Equation (1). To begin with work environmental hazards, the estimated coefficient on PHYHAZARD is positive and statistically significant at the 5 percent level $(p=0.024)$, confirming that workers exposed to physical hazards (noise and vibration) are more likely to quit their firms. To measure the size of the effect, we calculated the marginal effect of PHYHAZARD which suggests that exposure to 
physical hazards will result in an increase in the probability of employee turnover by 3 percentage points. Since the average turnover probability is 18 percent, the 3-percentage-point increase amounts to a significant 17-percent increase in voluntary turnover.

Unlike PHYHAZARD, we find the estimated coefficients on THERMHAZARD and CHEMHAZARD highly insignificant $(\mathrm{p}=0.429,0.715)$, suggesting no significant effect on employee turnover of the other two types of work environmental hazards. To be sure that the insignificance of these estimates is not due to multicollineality, we also estimated Eq. (2) with THERMHAZARD as the only work environmental hazard variable (excluding PHYHAZARD and CHEMHAZARD), and with CHEMHAZARD as the only work environmental hazard variable. We still failed to find any statistically significant effect on employee turnover of THERMHAZARD and CHEMHAZARD (not too surprisingly when we use PHYHAZARD as the only work environmental hazard variable, we still find the estimated coefficient on PHYHAZARD to be positive and statistically significant). ${ }^{8}$ Unlike our study, Bockerman and Ilmakunnas (2009) fail to find any evidence for the significant effect on employee turnover of work environmental hazards. Our study uses more concrete and disaggregated measures of work environmental hazards than their study. Such a measurement difference may account for the difference in the finding on the effect on employee turnover of work environmental hazards between the two studies.

Turning to scheduling hazards, what matters for employee turnover proves to be working in fixed night shifts (or the estimated coefficient on NIGHTSHIFT is positive and statistically significant at the 5 percent level $(\mathrm{p}=0.018)$. Our marginal effect calculation indicates that working in fixed night shift will lead to a decisive 12-percentage-point increase in employee request.

${ }^{8}$ These as well as all other unreported results are available from the corresponding author upon 
turnover from the average turnover of 18 percent, other things being equal. The estimated coefficients on all other scheduling hazard variables are not even close to significant at the 10 percent level. As in the case of the work environmental hazard variables, we considered each scheduling hazard variable alone without all other scheduling hazard variables and still found no evidence for the statistically significant relationship between employee turnover and scheduling hazards except for NIGHTSHIFT.

Whether the worker gets help from his/her boss is highly significantly correlated with his/her separation from the firm (the estimated coefficient on NOBOSSHELP is positive and highly significant at the 1 percent level) while getting help from his/her coworkers proves to be not at all related to his/her separation (the estimated coefficient on NOPEERHELP is highly insignificant with the value of $p$ being almost one). Calculating the marginal effect of NOBOSSHELP, we find that the price of having an unsupportive boss as expressed in higher employee turnover, is rather substantial (5.7-percentage point increase in employee turnover, other things being equal). Again, modifying Eq. (2) slightly using NOPEERHELP alone without NOBOSSHELP produces no discernable change.

Turning to conflict at work, we find no statistically significant relationship between employee turnover and any of the workplace conflict variables. To rule out the possibility that multicollineality among the three workplace conflict variables is resulting in imprecise estimates, we consider one workplace conflict variable at a time and still find the estimated coefficient on each variable insignificant even at the 10 percent level. Finally, the estimated coefficient on REPETITIVE is found to be also insignificant even at the 10 percent level.

With regard to HIWPs, the estimated coefficient on VOICE is negative and statistically significant at the 5 percent level, confirming our prior expectation of the turnover-reducing effect 
of VOICE. To gauge the magnitude of the benefit of VOICE, we calculate the marginal effects which point to nontrivial beneficial effects of VOICE. Granting VOICE to a worker will result in a 3.8 percentage-point reduction in his/her probability of separation from the firm. The estimated coefficients on INFOSHARE and TRAINING are also negative, consistent with our prior expectation although it is not statistically significant. Again, instead of nesting all three HIWP variables, we consider one HIWP variable at a time and still find that the estimated coefficient on VOICE is negative and statistically significant while the estimated coefficients on INFOSHARE and TRAINING are negative yet not statistically significant.

The estimated coefficients on the control variables are largely of expected signs and consistent with the literature. For example, as in the case of Bockerman and Ilmakunnas (2009), the estimated coefficient on TENURE is negative and significant at the 5 percent level, confirming what the human capital theory as well as the search theory predict.

Table 3 shows the results of our sensitivity analysis. First, we re-estimate the slightly parsimonious version of Eq. (1) with NIGTHSHIFT as the only scheduling hazard variable (dropping the other highly insignificant scheduling hazard variables); NOBOSSHELP as the only unsupportive workplace variable dropping NOPEERHELP; and dropping all three conflict at work variables (none of which is significant). As shown in Column (i) of Table 3, reassuringly the maximum likelihood estimates of the slightly parsimonious version of Eq. (1) are not noticeably different from those reported in Table 2.

Column (ii) of Table 3 indicates the robustness of the results to the use of the subjective measure of relative wage, or PRWAGE (=1 if the worker considers his/her current wage relative 
to his/her effort level and qualifications "high” or “appropriate” as opposed to “, zero otherwise) as an alternative to the objective measure, $\ln (\mathrm{ORWAGE}){ }^{9}$

Finally, we investigate the possible interplay between adverse workplace conditions and HIWPs. Specifically, we test the validity of our hypothesis that HIWPs may mitigate the turnover-increasing effect of adverse workplace conditions. Specifically, we augment Eq. (1) with an interaction term involving PHYHAZARD and each of the three HIWP variables (VOICE; INFORSHARE; and TRAINING). Likewise, we also consider an interaction term involving NIGHTSHIFT and each of the three HIWP variables as well as an interaction term involving NOBOSSHELP and each of the three HIWP variables. We select PHYHAZARD, NIGHTSHIFT, and NOBOSSHELP since they are shown to be statistically significant determinants of employee turnover (as discussed above).

Table 4 shows the maximum likelihood estimates of Equation (1) augmented by the interaction term involving PHYHAZARD and each HIWP variable. The estimated coefficient on PHYHAZARD*INFOSHARE is negative and significant at the 5 percent level $(p=0.025)$, suggesting that INFOSHARING does significantly mitigate the adverse impact on employee turnover of PHYHAZARD. In other words, we find evidence that the adverse effect on employee turnover of being exposed to physical hazards can be tempered by the High Involvement Work System which fosters strong information sharing and hence making workers feel fully informed of what is happening at their workplaces. The estimated coefficients on the other two interaction terms are found not at all significant. As such, we have no evidence for the mitigating role of VOICE and TRAINING in the adverse turnover effect of PHYHAZARD.

\footnotetext{
${ }^{9}$ In addition, we also consider DISSATISFY(=1 if the worker is not satisfied with his/her job, zero otherwise) as an additional explanatory variable. Our results change little even if we account for job satisfaction.
} 
The maximum likelihood estimates of Equation (1) augmented by the interaction term involving NIGHTSHIFT and each HIWP variable are reported in Table 5. The estimated coefficient on NIGHTSHFT*VOICE is negative and significant at the 5 percent level $(\mathrm{p}=0.036)$, again pointing to the significant mitigating role of VOICE in the adverse turnover effect of NIGHTSHIFT. As such we find evidence that the adverse effect on employee turnover of working in fixed night shifts can be reduced by the High Involvement Work System which enhances employee voice. We do not find the estimated coefficients on the other two interaction terms statistically significant. Finally, though not reported, the estimated coefficients on all interaction terms involving NOBOSSHELP and the HIWP variables are found not statistically significant and hence we find no evidence for any significant mitigating effect of HIWPs on the adverse effect on labor turnover of NOBOSSHELP.

\section{Long-run consequences on workplace conditions and HRM environments of turnover}

The 2005 Wave of the DWECS has just become available to us. Since the same individuals responded to the same set of questions on adverse workplace conditions and HRM in 2000 and 2005, we are able to uncover whether those who separated voluntarily from their firms in 2000 ended up with improved workplace conditions and HRM five years later. On our reading of the literature, we are the first to use such unusual linked employer-employee panel data and study the consequences on workplace conditions and HRM environments of voluntary separations. Specifically, we estimate the following logit model:

(2) $\ln [\operatorname{Pr}($ IMPROVE) $/ 1-\operatorname{Pr}($ IMPROVE) $]=\alpha+\beta$ TURNOVER + controls $+u$

For IMPROVE, based on the results presented in the previous sections, we consider three variables: PHYHAZARD, NOBOSSHELP, and VOICE. For PHYHAZARD, we first create a 
sample of workers with PHYHAZARD=1 (all workers exposed to physical hazards at the beginning of year 2000). For each worker in the sample, we find out whether she is still exposed to physical hazards five years later or at the beginning of 2005. We create a new variable IMPROVE which takes a value of 1 if she is no longer exposed to physical hazards (or PHYHAZARD=0), and zero otherwise. Likewise, for NOBOSSHELP, we create a sample of all workers with NOBOSSHELP=1 (all workers with unsupportive bosses at the beginning of 2000), and IMPROVE $=1$ if at the beginning of 2005 the worker no longer has an unsupportive boss (NOBOSSHELP=0), zero otherwise. Finally, for VOICE, a sample of all workers without strong voice in the workplace (VOICE=0) in 2000 is produced, and for each individual in the sample, IMPROVE takes a value of 1 if in 2005 she reports to have strong voice in the workplace (VOICE=1), zero otherwise.

Of prime interest is the coefficient on TURNOVER. The positive and significant coefficient suggests that voluntary separations from the firm will increase the 5-year odds of improved workplace conditions and HRM environments. To identify the effect of voluntary turnover separate from other factors that may also affect such an increase in the 5-year odds of improvements, we include as controls a series of dummy variables indicating: (i) whether the worker's occupation in 2005 is different from her occupation in 2000; (ii) whether the worker works in a different industry in 2005 from the one in 2000; (iii) whether the worker's firm size category changes from 2000 to 2005; (iv) whether the worker upgrades her education during the five-year period of 2000-2005; and (v) whether the worker lives in a different region in 2005 from the one in 2000, as well as her wage change from 2000 to 2005 and her age (in 2000).

Table 6 summarizes the maximum likelihood estimates of Equation (2). The estimated coefficients on TURNOVER for all three selected workplace conditions and HRM 
(PHYHAZARD, NOBOSSHELP, and VOICE) are positive and statistically significant (at the 1 percent level for PHYHAZARD and VOICE and at the 10 percent level for NOBOSSHELP). As such, our data support that changing the firm voluntarily does boost the odds of improved workplace conditions and HRM environments in five years, even if such turnover does not accompany any changes in occupation, industry, firm size, education, location, and wage.

To gauge the size of the effect of TURNOVER, we calculate the marginal effect estimates of Eq. (2) which illuminate that voluntary turnover leads to considerable improvements in workplace conditions and HRM environments. Specifically, by separating voluntarily from her firm, the worker exposed to physical hazards at the beginning of year 2000 can improve her 5-year odds of eliminating such physical hazard exposure by almost 20 percentage points. Since the average odds of escaping from physical hazards in five years is 40 percent, the estimated marginal effect of voluntary turnover (20 percentage point increase in the 5-year odds) amounts to a 50-percent improvement from the average. Likewise, for all workers with unsupporitve bosses, voluntary turnover will result in a 10-percentage-point increase in their odds of rectifying

this adverse workplace condition in five years (which amounts to a 14 percent improvement from the average 5-year odds of 70 percent). Finally, the worker without strong voice in the workplace can improve her odds of gaining such voice in five years by over 20 percentage points (which amounts to a 30 percent improvement in the 5-year odds from the avearge odds of 67 percent) if she quits the firm.

\section{$\underline{\text { 5. Concluding Remarks }}$}

This paper has contributed to the emerging strand of the empirical literature that takes advantage of new data on workplace-specific job attributes and voluntary employee turnover to 
shed fresh insights on the relationship between employee turnover and adverse workplace conditions and HRM environments. Our paper represents one of the first serious attempts to marry the two separately-developed literatures, the HIWP literature and the employee turnover literature with particular focus on adverse workplace conditions. We do so by studying not only a variety of adverse workplace conditions but also several key elements of the High-Involvement Work System as possible determinants of employee turnover, and exploring potentially important interplay between the two.

We have found evidence that workers in hazardous workplace conditions are indeed more likely to separate from their current employers voluntarily while HIWPs reduce employee turnover. Specifically, exposing a worker to physical hazards such as loud noise, vibration or poor lighting will lead to a 3 percentage point increase in the probability of turnover from the average turnover rate of 18 percent; working in a fixed night shift will result in an 11 percentage point jump in the turnover probability, and having an unsupportive boss will lead to a 5 percentage point increase. The effects of HIWPs are modest yet hardly negligible with a 4 percentage point reduction in the turnover probability from having voice in the workplace.

In addition, we have found some evidence for the role that HIWPs play in mitigating the effects on turnover of adverse workplace conditions. Or the turnover-increasing effect of physical hazards is found to be significantly reduced by the presence of strong information sharing whereas the turnover-fostering effect of the use of fixed night shift is also found to be significantly mitigated by the authority delegation to workers by management. As such, our evidence lends support to those who advocate the use of HIWPs for those firms with employee turnover problems due to hazardous workplace conditions. 
Finally, we have linked the 2000 data to the 2005 data and have provided new evidence on the consequence of voluntary turnover on workplace conditions and HRM environments. Our logit analysis of the odds of improving workplace conditions and HRM environments suggests that the worker exposed to adverse workplace conditions and HRM environments can improve her odds of rectifying such workplace adversities significantly by separating from the firm voluntarily. In short, voluntary turnover appears to be a rational worker response to adverse workplace conditions. Unless the firm actually alleviates its adverse workplace conditions directly or mitigates their effects on voluntary turnover through the High-Involvement Work System, workers exposed to adverse workplace conditions will continue to take the exit option. 
References

Addison, John T. and Belfield, Clive R. "The Impact of Financial Participation and Employee Involvement on Financial Performance: A Re-Estimation Using the 1998 WERS." Scottish Journal of Political Economy, 2000, 47(5), pp. 571-83.

Akerlof, George A.; Rose, Andrew K. and Yellen, Janet L. "Job Switching and Job Satisfaction in the U.S. Labor Market." Brookings Papers on Economic Activity, 1988, (2), pp. 495-582.

Altonji, Joseph G. and Paxson, Christina H. "Labor Supply Preferences, Hours Constraints, and Hours-Wage Trade-Offs." Journal of Labor Economics, 1988, 6(2), pp. 254-76.

Askenazy, Philippe and Moreno Galbis, Eva. "The Impact of Technological and Organizational Changes on Labor Flows: Evidence on French Establishments." Labour, 2007, 21(2), pp. 265-301.

Bartel, Ann P. "Human Resource Management and Organizational Performance: Evidence from Retail Banking." Industrial and Labor Relations Review, 2004, 57(2), pp. 181-203.

. "Wages, Nonwage Job Characteristics, and Labor Mobility." Industrial and Labor Relations Review, 1982, 35(4), pp. 578-89.

Batt, Rosemary. "Work Organization, Technology, and Performance in Customer Service and Sales." Industrial and Labor Relations Review, 1999, 52(4), pp. 539-64.

Batt, Rosemary; Colvin, Alexander J. S. and Keefe, Jeffrey. "Employee Voice, Human Resource Practices, and Quit Rates: Evidence from the Telecommunications Industry." Industrial and Labor Relations Review, 2002, 55(4), pp. 573-94.

Batt, Rosemary and Valcour, P. Monique. "Human Resources Practices as Predictors of Work-Family Outcomes and Employee Turnover." Industrial Relations, 2003, 42(2), pp. 189-220.

Bauer, Thomas K. and Bender, Stefan. "Technological Change, Organizational Change, and Job Turnover." Labour Economics, 2004, 11(3), pp. 265-91.

Bayo-Moriones, José Alberto; Galilea-Salvatierra, Pedro Javier and Merino-Díaz de Cerio, Javier. "Participation, Cooperatives and Performance: An Analysis of Spanish Manufacturing Firms," T. Kato and J. Pliskin, Determinants of the Incidence and the Effects of Participatory Organizations: Advances in the Economic Analysis of Participatory and Labor-Managed Firms. Amsterdam: Elsevier/JAI, 2003, 31-56.

Becker, Brian E. and Huselid, Mark A. "High Performance Work Systems and Firm Performance: A Synthesis of Research and Managerial Implications," G. R. Ferris, Research in Personnel and Human Resources Management. Stamford, Conn. and London: JAI Press, 1998, 53-101.

Becker, Gary S. Human Capital: A Theoretical and Empirical Analysis, with Special Reference to Education. Chicago: University of Chicago Press, 1964.

Berg, Peter. "The Performance Effects of Modular Production in the Apparel Industry." Industrial Relations, 1996, 35(3), pp. 356-73.

Bingley, Paul and Westergaard-Nielsen, Niels. "Returns to Tenure, Firm-Specific Human Capital and Worker Heterogeneity." International Journal of Manpower, 2003, 24(7), pp. 774-88.

Black, Sandra E. and Lynch, Lisa M. "How to Compete: The Impact of Workplace Practices and Information Technology on Productivity." Review of Economics and Statistics, 2001, 83(3), pp. 434-45. 
. "What's Driving the New Economy? The Benefits of Workplace Innovation." Economic Journal, 2004, 114(493), pp. F97-116.

Bockerman, Petri and Ilmakunnas, Pekka. "Job Disamenities, Job Satisfaction, Quit Intentions, and Actual Separations: Putting the Pieces Together." Industrial Relations, 2009, 48(1), pp. 73-96.

Boning, Brent; Ichniowski, Casey and Shaw, Kathryn. "Opportunity Counts: Teams and the Effectiveness of Production Incentives." Journal of Labor Economics, 2007, 25(4), pp. 613-50.

Buhai, Sebastian; Cottini, Elena and Westergard-Nielsen, Niels. "The Impact of Workplace Conditions on Firm Performance," Tinbergen Institute, Tinbergen Institute Discussion Papers: 08-077/3, 2008.

Cappelli, Peter and Neumark, David. "Do "High-Performance" Work Practices Improve Establishment-Level Outcomes?" Industrial and Labor Relations Review, 2001, 54(4), pp. 737-75.

Clark, Andrew E. "What Really Matters in a Job? Hedonic Measurement Using Quit Data." Labour Economics, 2001, 8(2), pp. 223-42.

Clark, Andrew and Georgellis, Yannis. "Job Satisfaction, Wage Changes, and Quits: Evidence from Germany," P. Sanfey and S. W. Polachek, Research in Labor Economics. Volume 17. Stamford, Conn. and London: JAI Press, 1998, 95-121.

Conyon, Martin J. and Freeman, Richard B. "Shared Modes of Compensation and Firm Performance: U.K. Evidence," NBER Working Paper No. 8448, 2001.

Davis, Steven J. and Haltiwanger, John. "Gross Job Flows," O. Ashenfelter and D. Card, Handbook of Labor Economics. Volume 3b. Amsterdam; New York and Oxford: Elsevier Science, North-Holland, 1999, 2711-805.

Delfgaauw, Josse. "Where to Go? Workers' Reasons to Quit and Intra- Vs. Interindustry Job Mobility." Applied Economics, 2007, 39(16-18), pp. 2057-67.

DeVaro, Jed. "Teams, Autonomy, and the Financial Performance of Firms." Industrial Relations, 2006, 45(2), pp. 217-69.

Doellgast, Virginia. "Collective Bargaining and High-Involvement Management in Comparative Perspective: Evidence from U.S. And German Call Centers." Industrial Relations, 2008, 47(2), pp. 284-319.

Dunlop, John T. and Weil, David. "Diffusion and Performance of Modular Production in the U.S. Apparel Industry." Industrial Relations, 1996, 35(3), pp. 334-55.

Eriksson, Tor. "The Effects of New Work Practices - Evidence from Employer-Employee Data," T. Kato and J. Pliskin, Determinants of the Incidence and the Effects of Participatory Organizations: Advances in the Economic Analysis of Participatory and Labor-Managed Firms. Amsterdam: Elsevier/JAI, 2003, 3-30.

Eriksson, Tor and Westergaard-Nielsen, Niels. "Wage and Labor Mobility in Denmark, 19802000," National Bureau of Economic Research, Inc, NBER Working Papers: 13064, 2007.

Farber, Henry S. "Mobility and Stability: The Dynamics of Job Change in Labor Markets," O. Ashenfelter and D. Card, Handbook of Labor Economics. Volume 3b. Amsterdam; New York and Oxford: Elsevier Science, North-Holland, 1999, 2439-83.

Fernie, Sue and Metcalf, David. "It's Not What You Pay It's the Way That You Pay It and That's What Gets Results: Jockeys' Pay and Performance." Labour, 1999, 13(2), pp. 385411. 
Flanagan, Robert J.; Strauss, George and Ulman, Lloyd. "Worker Discontent and Work Place Behavior." Industrial Relations, 1974, 13(2), pp. 101-23.

Freeman, Richard B. "Individual Mobility and Union Voice in the Labor Market." American Economic Review, 1976, 66(2), pp. 361-68.

. "Job Satisfaction as an Economic Variable." American Economic Review, 1978, 68(2), pp. 135-41.

Freeman, Richard; Kleiner, Morris and Ostroff, Cheri. "The Anatomy of Employee Involvement and Its Effects on Firms and Workers," NBER Working Paper No. 8050, 2000.

Gant, Jon; Ichniowski, Casey and Shaw, Kathryn. "Social Capital and Organizational Change in High-Involvement and Traditional Work Organizations." Journal of Economics and Management Strategy, 2002, 11(2), pp. 289-328.

Garcia-Serrano, Carlos. "Temporary Employment, Working Conditions and Expected Exits from Firms." Labour, 2004, 18(2), pp. 293-316.

Gronberg, Timothy J. and Reed, W. Robert. "Estimating Workers' Marginal Willingness to Pay for Job Attributes Using Duration Data." Journal of Human Resources, 1994, 29(3), pp. 911-31.

Grund, Christian and Westergaard-Nielsen, Niels. "The Dispersion of Employees' Wage Increases and Firm Performance." Industrial and Labor Relations Review, 2008, 61(4), pp. 485-501.

Hamilton, Barton H.; Nickerson, Jack A. and Owan, Hideo. "Team Incentives and Worker Heterogeneity: An Empirical Analysis of the Impact of Teams on Productivity and Participation." Journal of Political Economy, 2003, 111(3), pp. 465-98.

Helper, Susan. "Complementarity and Cost Reduction: Evidence from the Auto Supply Industry," Working Paper No. 6033 (revised). Cambridge, MA: National Bureau of Economic Research, 1998.

Herzog, Henry W., Jr. and Schlottmann, Alan M. "Valuing Risk in the Workplace: Market Price, Willingness to Pay, and the Optimal Provision of Safety." Review of Economics and Statistics, 1990, 72(3), pp. 463-70.

Heywood, John S.; Jirjahn, Uwe and Wei, Xiangdong. "Teamwork, Monitoring and Absence." Journal of Economic Behavior \& Organization, 2008, 68(3/4), pp. 676-90.

Huselid, Mark A. "The Impact of Human Resource Management Practices on Turnover, Productivity, and Corporate Financial Performance." Academy of Management Journal, 1995, 38, pp. 635-72.

Huselid, Mark A. and Becker, Brian E. "Methodological Issues in Cross-Sectional and Panel Estimates of the Human Resource-Firm Performance Link." Industrial Relations, 1996, 35(3), pp. 400-22.

Ichniowski, Casey; Shaw, Kathryn and Prennushi, Giovanna. "The Effects of Human Resource Management Practices on Productivity: A Study of Steel Finishing Lines." American Economic Review, 1997, 87(3), pp. 291-313.

Jones, Derek C.; Kalmi, Panu and Kauhanen, Antti. "Human Resource Management Policies and Productivity: New Evidence from an Econometric Case Study." Oxford Review of Economic Policy, 2006, 22(4), pp. 526-38.

Jones, Derek C. and Kato, Takao. "The Productivity Effects of Employee Stock-Ownership Plans and Bonuses: Evidence from Japanese Panel Data." American Economic Review, 1995, 85(3), pp. 391-414. 
Karasek, R. and Theorell, T. Healthy Work: Stress, Productivity, and the Reconstruction of Working Life. New York, NY Basic Books, 1990.

Kato, Takao and Morishima, Motohiro. "The Productivity Effects of Participatory Employment Practices: Evidence from New Japanese Panel Data." Industrial Relations, 2002, 41(4), pp. 487-520.

Kidd, Michael P. "Some Canadian Evidence on the Quit/Lay-Off Distinction." Canadian Journal of Economics, 1994, 27(3), pp. 709-33.

Kleiner, Morris and Helper, Susan. "Changing Incentives for Production Employees: Impacts on Establishment Economic Outcomes and Worker Satisfaction," Paper presented at the 55th IRRA meeting, Washington, D.C., 2003.

Koike, Kazuo. Shigoto No Keizaigaku (Economics of Work). Tokyo: Toyo Keizai, 2005.

Kristensen, Nicolai and Westergard-Nielsen, Niels. "Job Satisfaction and Quits--Which Job Characteristics Matters Most?" Nationalokonomisk Tidsskrift, 2006, 144(2), pp. 230-48.

Lawler, Edward E; Mohrman, Susan A. and Ledford, Gerald. Creating High Performance Organizations. San Francisco: Jossey-Bass, 1995.

Lazear, Edward P. "Performance Pay and Productivity." American Economic Review, 2000, 90(5), pp. 1346-61.

Leoni, Riccardo; Cristini, Annalisa; Labory, Sandrine and Gaj, Alessandro. "New Work Practices in Italy - Adoption and Performance Effects," Paper presented at the International Conference on Organizational Design, Management Styles and Firm Performance, University of Bergamo, Bergamo, Italy, 2001.

Levy-Garboua, Louis; Montmarquette, Claude and Simonnet, Veronique. "Job Satisfaction and Quits." Labour Economics, 2007, 14(2), pp. 251-68.

Paarsch, Harry J. and Shearer, Bruce S. "The Response of Worker Effort to Piece Rates: Evidence from the British Columbia Tree-Planting Industry." Journal of Human Resources, 1999, 34(4), pp. 643-67.

Siegrist, J. "Adverse Health Effects of High-Effort/Low Reward Conditions." Journal of Occupational Health Psychology, 1996, 1, pp. 27-41.

Viscusi, W. Kip. "Job Hazards and Worker Quit Rates: An Analysis of Adaptive Worker Behavior." International Economic Review, 1979, 20(1), pp. 29-58.

Ward, Melanie E. and Sloane, Peter J. "Non-Pecuniary Advantages Versus Pecuniary Disadvantages; Job Satisfaction among Male and Female Academics in Scottish Universities." Scottish Journal of Political Economy, 2000, 47(3), pp. 273-303.

Zwick, Thomas. "Employee Participation and Productivity." Labour Economics, 2004, 11(6), pp. 715-40. 
Table1: Summary Statistics (Mean)

\begin{tabular}{lccc}
\hline & ALL & TURNOVER=1 & TURNOVER=0 \\
\hline PHYHAZARD & 0.435 & 0.501 & 0.421 \\
THERMHAZARD & 0.427 & 0.467 & 0.419 \\
CHEMHAZARD & 0.294 & 0.308 & 0.291 \\
SHIFTWORK & 0.133 & 0.149 & 0.129 \\
MORNINGSHIFT & 0.004 & 0.005 & 0.004 \\
EVENINGSHIFT & 0.021 & 0.020 & 0.022 \\
NIGHTSHIFT & 0.017 & 0.029 & 0.014 \\
NOBOSSHELP & 0.182 & 0.241 & 0.168 \\
NOPEERHELP & 0.078 & 0.091 & 0.074 \\
BULLYING & 0.053 & 0.064 & 0.051 \\
UNWANTEDSEX & 0.013 & 0.009 & 0.014 \\
VIOLENCE & 0.052 & 0.045 & 0.054 \\
REPETITIVE & 0.528 & 0.567 & 0.521 \\
VOICE & 0.797 & 0.712 & 0.815 \\
INFOSHARE & 0.909 & 0.867 & 0.918 \\
TRAINING & 0.526 & 0.482 & 0.536 \\
AGE & 40.002 & 36.429 & 40.789 \\
TENURE & 6.337 & 4.224 & 6.802 \\
EDUCATION & 13.199 & 13.278 & 13.182 \\
FEMALE & 0.454 & 0.380 & 0.471 \\
MARRIED & 0.574 & 0.498 & 0.591 \\
\hline N & 3057 & 552 & 2505 \\
\hline \hline SOIICES: StatiSticS Dent
\end{tabular}

Sources: Statistics Denmark Integrated Labour Market Database (IDA) from the Danish Bureau of Statistics and Danish Work Environment Cohort Study (DWECS) collected by the Institute for Occupational Health (AMI).

Notes: The data are for the private sector only. For variable definitions, see the text. 
Table 2 The Effect on Labor Turnover of Adverse Working Conditions and High Involvement Work Practices: Logit Estimates

\begin{tabular}{|c|c|c|c|}
\hline & \multicolumn{3}{|c|}{ (i) } \\
\hline & \multicolumn{3}{|c|}{ robust } \\
\hline & coeff. & s.e. & p_value \\
\hline \multicolumn{4}{|c|}{ WORK ENVIRONMENTAL HAZARDS } \\
\hline PHYHAZARD & 0.253 & 0.113 & 0.024 \\
\hline THERMHAZARD & -0.093 & 0.118 & 0.429 \\
\hline CHEMHAZARD & -0.044 & 0.121 & 0.715 \\
\hline \multicolumn{4}{|c|}{ SCHEDULING HAZARDS } \\
\hline SHIFTWORK & 0.211 & 0.155 & 0.175 \\
\hline MORNINGSHIFT & 0.346 & 0.707 & 0.624 \\
\hline EVENINGSHIFT & -0.065 & 0.399 & 0.872 \\
\hline NIGHTSHIFT & 0.760 & 0.320 & 0.018 \\
\hline \multicolumn{4}{|c|}{ UNSUPPORTIVE BOSS AND COWORKERS } \\
\hline NOBOSSHELP & 0.414 & 0.134 & 0.002 \\
\hline NOPEERHELP & 0.034 & 0.194 & 0.861 \\
\hline \multicolumn{4}{|c|}{ CONFLICT AT WORK } \\
\hline BULLYING & 0.129 & 0.223 & 0.562 \\
\hline UNWANTEDSEX & -0.565 & 0.455 & 0.215 \\
\hline VIOLENCE & -0.027 & 0.271 & 0.920 \\
\hline \multicolumn{4}{|l|}{ REPETITIVE WORK } \\
\hline REPETITIVE & -0.009 & 0.113 & 0.938 \\
\hline \multicolumn{4}{|c|}{ HIGH-INVOLVEMENT WORK PRACTICES } \\
\hline VOICE & -0.284 & 0.136 & 0.037 \\
\hline INFOSHARE & -0.125 & 0.179 & 0.484 \\
\hline TRAINING & -0.140 & 0.111 & 0.205 \\
\hline \multicolumn{4}{|c|}{ CONTROL VARIABLES } \\
\hline AGE & -0.071 & 0.041 & 0.086 \\
\hline $\mathrm{AGE}^{2}$ & 0.001 & 0.000 & 0.210 \\
\hline TENURE & -0.077 & 0.040 & 0.056 \\
\hline TENURE $^{2}$ & 0.002 & 0.001 & 0.186 \\
\hline EDUCATION & 0.024 & 0.024 & 0.318 \\
\hline FEMALE & -0.125 & 0.117 & 0.285 \\
\hline MARRIED & 0.044 & 0.115 & 0.702 \\
\hline ORWAGE & -0.179 & 0.215 & 0.404 \\
\hline occupation dummy & Yes & & \\
\hline industry dummy & Yes & & \\
\hline region dummy & Yes & & \\
\hline firm sizes dummy & Yes & & \\
\hline $\mathrm{N}$ & 2963 & & \\
\hline Pseudo $\mathrm{R}^{2}$ & 0.106 & & \\
\hline
\end{tabular}

Sources: Statistics Denmark Integrated Labour Market Database (IDA) from the Danish Bureau of Statistics and Danish Work Environment Cohort Study (DWECS) collected by the Institute for Occupational Health (AMI).

Notes: The data are for the private sector only. For variable definitions, see the text. 
Table 3 Robustness Check: Using subjective relative wage measure

\begin{tabular}{|c|c|c|c|c|c|c|}
\hline & \multicolumn{3}{|c|}{ (i) } & \multicolumn{3}{|c|}{ (ii) } \\
\hline & \multicolumn{3}{|c|}{ robust } & \multicolumn{3}{|c|}{ robust } \\
\hline & coeff. & s.e. & p_value & coeff. & s.e. & p_value \\
\hline PHYHAZARD & 0.257 & 0.111 & 0.021 & 0.277 & 0.107 & 0.010 \\
\hline THERMHAZARD & -0.119 & 0.116 & 0.303 & -0.156 & 0.112 & 0.163 \\
\hline CHEMHAZARD & -0.027 & 0.118 & 0.819 & 0.016 & 0.113 & 0.888 \\
\hline NIGHTSHIFT & 0.719 & 0.312 & 0.021 & 0.630 & 0.313 & 0.044 \\
\hline NOBOSSHELP & 0.415 & 0.129 & 0.001 & 0.421 & 0.124 & 0.001 \\
\hline REPETITIVE & 0.023 & 0.111 & 0.837 & -0.025 & 0.106 & 0.815 \\
\hline VOICE & -0.320 & 0.133 & 0.016 & -0.265 & 0.129 & 0.039 \\
\hline INFOSHARE & -0.194 & 0.174 & 0.264 & -0.146 & 0.167 & 0.381 \\
\hline TRAINING & -0.124 & 0.109 & 0.257 & -0.154 & 0.105 & 0.140 \\
\hline AGE & -0.073 & 0.040 & 0.070 & -0.056 & 0.033 & 0.088 \\
\hline$A G E^{2}$ & 0.001 & 0.000 & 0.165 & 0.000 & 0.000 & 0.295 \\
\hline TENURE & -0.082 & 0.040 & 0.038 & -0.107 & 0.024 & 0.000 \\
\hline TENURE $^{2}$ & 0.002 & 0.001 & 0.160 & 0.002 & 0.001 & 0.033 \\
\hline EDUCATION & 0.020 & 0.024 & 0.394 & 0.037 & 0.023 & 0.108 \\
\hline FEMALE & -0.116 & 0.115 & 0.315 & -0.057 & 0.109 & 0.599 \\
\hline MARRIED & 0.027 & 0.113 & 0.810 & 0.046 & 0.109 & 0.670 \\
\hline ORWAGE & -0.174 & 0.212 & 0.412 & & & \\
\hline PRWAGE & & & & 0.095 & 0.099 & 0.336 \\
\hline occupation & & & & & & \\
\hline dummy & yes & & & yes & & \\
\hline industry dummy & yes & & & yes & & \\
\hline region dummy & yes & & & yes & & \\
\hline firm sizes dummy & yes & & & yes & & \\
\hline $\mathrm{N}$ & 3057 & & & 3230 & & \\
\hline Pseudo $\mathrm{R}^{2}$ & 0.106 & & & 0.096 & & \\
\hline
\end{tabular}

Sources: Statistics Denmark Integrated Labour Market Database (IDA) from the Danish Bureau of Statistics and Danish Work Environment Cohort Study (DWECS) collected by the Institute for Occupational Health (AMI).

Notes: The data are for the private sector only. For variable definitions, see the text. 
Table 4 The Effect on Labor Turnover of Adverse Working Conditions and High Involvement Work Practices: Logit Estimates with an Interaction Term involving PHYHAZARD and HIWP

\begin{tabular}{|c|c|c|c|c|c|c|c|c|c|}
\hline & \multirow{2}{*}{\multicolumn{3}{|c|}{$\begin{array}{c}\text { (i) } \\
\text { HIWP= } \\
\text { VOICE } \\
\text { robust }\end{array}$}} & \multicolumn{3}{|c|}{$\begin{array}{c}\text { (ii) } \\
\text { HIWP= } \\
\text { INFOSHARE }\end{array}$} & \multicolumn{3}{|c|}{$\begin{array}{c}\text { (iii) } \\
\text { HIWP= } \\
\text { TRAINING }\end{array}$} \\
\hline & & & & \multirow[b]{2}{*}{ coeff. } & \multirow[b]{2}{*}{ robust s.e. } & \multirow[b]{2}{*}{ p_value } & \multirow[b]{2}{*}{ coeff. } & \multirow[b]{2}{*}{ robust s.e. } & \multirow[b]{2}{*}{ p_value } \\
\hline & coeff. & s.e. & p_value & & & & & & \\
\hline PHYHAZARD & 0.208 & 0.212 & 0.326 & 1.036 & 0.372 & 0.005 & 0.363 & 0.149 & 0.015 \\
\hline THERMHAZARD & -0.120 & 0.116 & 0.301 & -0.121 & 0.116 & 0.299 & -0.120 & 0.116 & 0.300 \\
\hline CHEMHAZARD & -0.027 & 0.118 & 0.821 & -0.033 & 0.119 & 0.783 & -0.029 & 0.119 & 0.804 \\
\hline NIGHTSHIFT & 0.719 & 0.311 & 0.021 & 0.715 & 0.311 & 0.022 & 0.710 & 0.313 & 0.023 \\
\hline NOBOSSHELP & 0.415 & 0.129 & 0.001 & 0.402 & 0.130 & 0.002 & 0.414 & 0.129 & 0.001 \\
\hline REPETITIVE & 0.022 & 0.111 & 0.840 & 0.022 & 0.111 & 0.844 & 0.025 & 0.111 & 0.820 \\
\hline VOICE & -0.355 & 0.187 & 0.058 & -0.313 & 0.134 & 0.019 & -0.318 & 0.133 & 0.017 \\
\hline INFOSHARE & -0.199 & 0.174 & 0.253 & 0.401 & 0.336 & 0.233 & -0.189 & 0.174 & 0.277 \\
\hline TRAINING & -0.123 & 0.109 & 0.258 & -0.127 & 0.109 & 0.247 & -0.021 & 0.146 & 0.887 \\
\hline PHYHAZARD*HIWP & 0.066 & 0.239 & 0.783 & -0.855 & 0.383 & 0.025 & -0.217 & 0.204 & 0.288 \\
\hline AGE & -0.073 & 0.040 & 0.069 & -0.072 & 0.040 & 0.074 & -0.072 & 0.040 & 0.073 \\
\hline $\mathrm{AGE}^{2}$ & 0.001 & 0.000 & 0.163 & 0.001 & 0.000 & 0.165 & 0.001 & 0.000 & 0.168 \\
\hline TENURE & -0.083 & 0.040 & 0.037 & -0.079 & 0.040 & 0.045 & -0.082 & 0.040 & 0.039 \\
\hline TENURE $^{2}$ & 0.002 & 0.001 & 0.158 & 0.002 & 0.001 & 0.182 & 0.002 & 0.001 & 0.162 \\
\hline EDUCATION & 0.021 & 0.024 & 0.388 & 0.018 & 0.024 & 0.450 & 0.020 & 0.024 & 0.405 \\
\hline FEMALE & -0.115 & 0.115 & 0.316 & -0.120 & 0.116 & 0.301 & -0.115 & 0.115 & 0.318 \\
\hline MARRIED & 0.027 & 0.113 & 0.810 & 0.024 & 0.113 & 0.834 & 0.024 & 0.113 & 0.828 \\
\hline ORWAGE & -0.170 & 0.212 & 0.422 & -0.193 & 0.212 & 0.364 & -0.180 & 0.212 & 0.397 \\
\hline occupation dummy & yes & & & yes & & & yes & & \\
\hline industry dummy & yes & & & yes & & & yes & & \\
\hline region dummy & yes & & & yes & & & yes & & \\
\hline firm sizes dummy & yes & & & yes & & & yes & & \\
\hline $\mathrm{N}$ & 3057 & & & 3057 & & & 3057 & & \\
\hline Pseudo $\mathrm{R}^{2}$ & 0.107 & & & 0.108 & & & 0.107 & & \\
\hline
\end{tabular}

Sources: Statistics Denmark Integrated Labour Market Database (IDA) from the Danish Bureau of Statistics and Danish Work Environment Cohort Study (DWECS) collected by the Institute for Occupational Health (AMI).

Notes: The data are for the private sector only. For variable definitions, see the text. 
Table 5 The Effect on Labor Turnover of Adverse Working Conditions and High Involvement Work Practices: Logit Estimates with an Interaction Term involving NIGHTSHIFT and HIWP

\begin{tabular}{|c|c|c|c|c|c|c|c|c|c|}
\hline & \multirow{2}{*}{\multicolumn{3}{|c|}{$\begin{array}{c}\text { (i) } \\
\text { HIWP= } \\
\text { VOICE }\end{array}$}} & \multicolumn{3}{|c|}{$\begin{array}{c}\text { (ii) } \\
\text { HIWP= } \\
\text { INFOSHARE }\end{array}$} & \multicolumn{3}{|c|}{$\begin{array}{c}\text { (iii) } \\
\text { HIWP= } \\
\text { TRAINING }\end{array}$} \\
\hline & & & & & & & & & \\
\hline & coeff. & s.e. & p_value & coeff. & robust s.e. & p_value & coeff. & robust s.e. & p_value \\
\hline PHYHAZARD & 0.259 & 0.111 & 0.020 & 0.257 & 0.111 & 0.021 & 0.256 & 0.111 & 0.021 \\
\hline THERMHAZARD & -0.118 & 0.116 & 0.309 & -0.121 & 0.116 & 0.297 & -0.119 & 0.116 & 0.306 \\
\hline CHEMHAZARD & -0.028 & 0.118 & 0.814 & -0.024 & 0.118 & 0.840 & -0.027 & 0.118 & 0.820 \\
\hline NIGHTSHIFT & 1.408 & 0.490 & 0.004 & 1.512 & 0.801 & 0.059 & 0.769 & 0.410 & 0.060 \\
\hline NOBOSSHELP & 0.417 & 0.129 & 0.001 & 0.417 & 0.129 & 0.001 & 0.415 & 0.129 & 0.001 \\
\hline REPETITIVE & 0.023 & 0.111 & 0.839 & 0.023 & 0.111 & 0.834 & 0.022 & 0.111 & 0.840 \\
\hline VOICE & -0.272 & 0.136 & 0.045 & -0.318 & 0.133 & 0.017 & -0.320 & 0.133 & 0.016 \\
\hline INFOSHARE & -0.194 & 0.174 & 0.266 & -0.156 & 0.178 & 0.381 & -0.195 & 0.174 & 0.262 \\
\hline TRAINING & -0.132 & 0.109 & 0.227 & -0.128 & 0.109 & 0.242 & -0.121 & 0.111 & 0.274 \\
\hline NIGHTSHIFT*HIWP & -1.401 & 0.668 & 0.036 & -0.992 & 0.875 & 0.257 & -0.106 & 0.622 & 0.865 \\
\hline AGE & -0.071 & 0.040 & 0.080 & -0.074 & 0.040 & 0.067 & -0.073 & 0.040 & 0.070 \\
\hline $\mathrm{AGE}^{2}$ & 0.001 & 0.000 & 0.175 & 0.001 & 0.000 & 0.156 & 0.001 & 0.000 & 0.164 \\
\hline TENURE & -0.077 & 0.040 & 0.051 & -0.080 & 0.039 & 0.043 & -0.083 & 0.040 & 0.037 \\
\hline TENURE $^{2}$ & 0.002 & 0.001 & 0.213 & 0.002 & 0.001 & 0.195 & 0.002 & 0.001 & 0.157 \\
\hline EDUCATION & 0.019 & 0.024 & 0.437 & 0.020 & 0.024 & 0.411 & 0.020 & 0.024 & 0.395 \\
\hline FEMALE & -0.121 & 0.115 & 0.293 & -0.117 & 0.115 & 0.312 & -0.115 & 0.115 & 0.316 \\
\hline MARRIED & 0.020 & 0.113 & 0.863 & 0.027 & 0.113 & 0.812 & 0.028 & 0.113 & 0.806 \\
\hline ORWAGE & -0.197 & 0.213 & 0.354 & -0.180 & 0.213 & 0.396 & -0.174 & 0.212 & 0.412 \\
\hline occupation dummy & yes & & & yes & & & yes & & \\
\hline industry dummy & yes & & & yes & & & yes & & \\
\hline region dummy & yes & & & yes & & & yes & & \\
\hline firm sizes dummy & yes & & & yes & & & yes & & \\
\hline $\mathrm{N}$ & 3057 & & & 3057 & & & 3057 & & \\
\hline Pseudo $\mathrm{R}^{2}$ & 0.108 & & & 0.107 & & & 0.107 & & \\
\hline
\end{tabular}

Sources: Statistics Denmark Integrated Labour Market Database (IDA) from the Danish Bureau of Statistics and Danish Work Environment Cohort Study (DWECS) collected by the Institute for Occupational Health (AMI).

Notes: The data are for the private sector only. For variable definitions, see the text. . 
Table 6 Five-year odds of workplace improvements with and without Turnover: Logit Estimates Dependent Variable=IMPROVE

\begin{tabular}{|c|c|c|c|c|c|c|c|c|c|}
\hline \multirow[b]{4}{*}{ Variable } & \multicolumn{6}{|c|}{ IMPROVE in: } & \multirow{2}{*}{\multicolumn{3}{|c|}{ VOICE }} \\
\hline & \multirow{2}{*}{\multicolumn{3}{|c|}{ PHYHAZARD }} & \multicolumn{3}{|c|}{ NOBOSSHELP } & & & \\
\hline & & & & & & & \multicolumn{3}{|c|}{ robust } \\
\hline & coeff. & s.e. & $p$ value & coeff. & robust s.e. & p_value & coeff. & s.e. & p_value \\
\hline TURNOVER & 0.697 & 0.166 & 0.000 & 0.554 & 0.295 & 0.060 & 1.028 & 0.311 & 0.001 \\
\hline $\mathrm{N}$ & 848 & & & 321 & & & 343 & & \\
\hline Pseudo $\mathrm{R}^{2}$ & 0.040 & & & 0.035 & & & 0.073 & & \\
\hline
\end{tabular}

Sources: Statistics Denmark Integrated Labour Market Database (IDA) from the Danish Bureau of Statistics and Danish Work Environment Cohort Study (DWECS) collected by the Institute for Occupational Health (AMI).

Notes: Notes: The data are for the private sector only. For variable definitions, see the text. All models include as controls a series of dummy variables indicating: (i) whether the worker's occupation in 2005 is different from her occupation in 2000; (ii) whether the worker works in a different industry in 2005 from the one in 2000; (iii) whether the worker's firm size category changes from 2000 to 2005; (iv) whether the worker upgrades her education during the five-year period of 2000-2005; and (v) whether the worker lives in a different region in 2005 from the one in 2000, as well as her wage change from 2000 to 2005 and her age (in 2000). 